\title{
The Effects of Task-based Instruction Using a Digital Game in a Flipped Learning Environment on English Oral Communication Ability of Thai Undergraduate Nursing Students
}

\author{
Suphatha Rachayon ${ }^{1} \&$ Kittitouch Soontornwipast ${ }^{1}$ \\ ${ }^{1}$ Language Institute, Thammasat University, Bangkok, Thailand \\ Correspondence: Suphatha Rachayon, Language Institute, Thammasat University, Prachan Road, Bangkok \\ 10200, Thailand.
}

Received: April 28, 2019 Accepted: May 30, 2019 Online Published: June 2, 2019

doi: 10.5539/elt.v12n7p12 URL: https://doi.org/10.5539/elt.v12n7p12

\begin{abstract}
The growth of Thailand's medical tourism industry has inevitably made English oral communication skills become increasingly important to Thai medical personnel, especially to nurses who have to act as medical mediators between doctors and patients. Thus, in order to prepare nursing students for their future career, it is necessary that English teachers find a way to help students improve their oral communication ability. Thus, in this study, as a means to overcome the students' difficulties in learning English and to enhance their English oral communication ability, the task-based instruction using a digital game in a flipped learning environment (TGF) was developed by integrating three language learning approaches, namely task-based language teaching, flipped learning, and digital game-based language learning. The development of the instructional framework for the TGF was described first. Then, to investigate its effectiveness in improving the students' oral communication ability, an experimental study, using a one-group pretest posttest design, was conducted with 23 second-year nursing students at a private university in Thailand for 11 weeks. The effects of the TGF on the students' oral communication ability were assessed by the participants' pre- and post-test. The finding revealed that the participants' average post-test score was statistically significantly higher than their average pre-test score ( $\mathrm{p}<$ 0.05), indicating that the TGF was successful in enhancing the students' oral communication ability. Lastly, the factors contributing to this success were discussed.
\end{abstract}

Keywords: task-based language teaching, flipped learning, digital game, oral communication ability, nursing students

\section{Introduction}

Medical tourism is a star industry in Thailand. The number of international patients receiving medical treatment in Thailand, according to Thai Ministry of Commerce (2015, cited in Thailand Board of Investment, 2016), rose $10.96 \%$ from 1.6 million people in 2009 to 2.4 million people in 2014 . This number is expected to increase continually due to the implementation of ASEAN Economic Community (AEC) in 2015, plus the policies of Thai government to turn the country into the medical hub of Asia within the 2016-2025 period (Thailand Board of Investment, 2017). The growth of Thailand's medical tourism industry, according to Rerkrujipimol and Assenov (2011), Supakankunti and Herberholz (2011), and Amornvivat (2012), has inevitably made English language skills become increasingly important to Thai medical personnel, especially to nurses who have to act as medical mediators between doctors and patients.

\subsection{English Oral Communication Difficulties of Nursing Students}

As one of the best nursing schools in Thailand, the faculty of Nursing at the researcher's workplace, a private university in Samutprakarn province, realizes the significance of English language skills to its nursing students' future. Hence, the university offers 4 required English courses to nursing students, 2 courses of general English and 2 courses of English for Specific Purposes. However, the nursing graduates still have a problem in using English as seen from the 2014-2015 graduate employment survey, in which $80 \%$ of the graduates' employers stated that the graduates needed to improve their English communication skills. This is in line with the graduates themselves, who also mentioned English deficiency as a key obstacle preventing them from finding a job. Some said that they were unable to get a well-paid job in an international hospital because they were unable to obtain 
the minimum required score on a TOEIC or TOEFL test. In fact, while studying at the university, these nursing students also faced difficulties in learning English. Most of them only achieved a C or C + grade (with the average scores ranging from 60 to 65 out of 100) on 4 required English courses. According to experienced English teachers and the students themselves, of all four main skills, speaking seemed to be the biggest problem for the nursing students. The students could not communicate in English with their classmates and teachers and most lacked confidence when speaking English. They did not voluntarily speak English in front of the classroom and tended to avoid responding to teacher's questions. Some were so afraid of speaking English that they deliberately did not attend the necessary oral tests. Similarly, the students themselves perceived that speaking English was their serious problem. Most admitted that they wanted to speak but they were afraid of making mistakes by using incorrect grammar or mispronouncing words, which might make them 'lose face' in front of their classmates. However, according to many scholars and researchers (Alharby, 2005; Tasci, 2007; Waidarp, 2011; and Pandey \& Sinhaneti, 2013) listening-speaking skills are perceived as the most important language skills in the careers of health professionals. Thus, in order to prepare nursing students for their future career, improving listening and speaking skills must be a top priority for language teachers.

\subsection{Factors Contributing to English Oral Communication Difficulties of Nursing Students}

After observing the English oral communication classes at this university and interviewing with both teachers and students, the researcher found a number of factors contributing to the nursing students' difficulties in speaking English. First, the students lacked enough opportunities to practice speaking English. As English is used as a foreign language in Thailand, the students have limited opportunities to practice speaking English outside the classroom (Foley, 2005). However, even in English classes, the students were not provided with enough opportunities to practice speaking English (Wiriyachitra, 2001; Khamkhien, 2010; Noom-Ura, 2013). This was due to a problem of large classes consisting of mixed-ability students, which caused difficulties for teachers not only to design learning activities that were suitable for all students but also to provide enough time for each student to practice their speaking skills and to give feedback on their performance individually. Thus, it was found that teachers tended to use teacher-centered approach in which the teacher did most of the talking, explaining grammatical structures and vocabulary, while students listened and sat passively. Some teachers played audios and let students repeat sentences out loud or provided students with a set of pattern drills and let students memorize them. It is likely that these teaching methods made some students feel bored and developed negative attitudes toward learning English. Besides, the students' personalities were also another main obstacle preventing them from improving their oral communication skill. The students were shy and lacked confidence to speak English with teachers or classmates. Some were nervous in English speaking classes and tended to avoid speaking English because they were afraid of making mistakes and 'losing face' in front of others. Moreover, the activities and textbooks used in the classes were not motivating enough to encourage the students to speak (Sangboon, 2004; Kanoksilapatham, 2007). Based on these context and problems, it is necessary that a new teaching method should be implemented into the English classes.

\subsection{Task-based Language Teaching (TBLT): The First Step to the Solution}

In order to find an effective way to solve the above-mentioned problems and enhance the nursing students' oral communication ability, a number of literature and previous studies related to English teaching and learning were reviewed. Task-based language teaching (TBLT), compared with other language teaching approaches, seems to be the most suitable for the present study. TBLT is a communicative and interactive approach to language learning (Van den Branden, 2016). Through its three main phases- pre-task, during task and post-task, TBLT promotes language acquisition by providing a rich and comprehensive exposure to language in use as well as plenty of opportunities to use the language to negotiate with others for meaning (Nunan, 1989; Willis, 1996; Ellis, 2003; and Samuda \& Bygate, 2008). Since the focus is on using the language to do things which are related to their personal lives outside the classroom, TBLT is then an exciting and motivating approach (Van den Branden, 2016). It also helps learners strengthen their social skills, problem-solving, interpreting, planning, and decision-making skills, which are essential skills for nursing students (Willis, 2000; Ellis, 2003). Besides, by letting the learners do things in pairs or groups, TBLT also fits well in mixed-ability large class (Willis \& Willis, 2007).

However, a number of studies investigating the implementation of TBLT in Asian contexts (Bruton, 2005; Littlewood, 2007; Carless, 2007; McDonough \& Chaikitmongkol, 2007; Burrows, 2008; and Mustafa, 2008), reported various challenges including a lack of time to do tasks in class, students' lack of initiative in task performance due to their shyness to speak English, avoidance of using English and overreliance on L1 when doing tasks. Besides, it was also found that lower-ability students had negative attitudes towards TBLT, thinking that it was too demanding for them. Since the students in the present study shared similar characteristics with the 
participants in the aforementioned previous studies, it could be predictable that the researcher might face such problems. Thus, before implementation, TBLT needed to be adapted first.

Having considered the TBLT framework, the researcher found that the possible factor that may contribute to these problems is the pre-task phase. According to Willis (2000), the pre-task phase, which aims to help students define the topic area, recall and activate words or phrases, give task instructions, and provide students with a task model, should be the shortest phase in the TBLT framework, lasting only 2-20 minutes. However, in a large class which consists of mixed-proficiency students, to meet these objectives seems to take longer time than expected. Moreover, for lower-ability students, to be able to perform a task, they need more time to memorize words or phrases that are necessary for doing a task. Similarly, for introverted students, they also need to spend some time learning and practicing words or phrases individually, listening to others, or observing others until they gain some confidence to use the language to perform a task (Willis, 2000). If these students are not ready, when doing a task, teachers will often find it difficult to get them talk. However, if teachers spend more time to pre-teach words or phrases before letting students perform a task, higher-proficiency students who know them already will be bored and feel they are wasting time. Besides, extending pre-task phase also causes a problem of insufficient time for students to perform a task and reflect upon their task performance. A lack of enough opportunities to practice and reflect on their speaking ability therefore contributes to their difficulties in speaking English.

\subsection{Flipped Learning: The Second Step to the Solution}

Having reviewed further materials on learning principles and theories, the researcher found that the concept of flipped learning could be integrated into TBLT in order to overcome the challenges mentioned above. According to Bergmann and Sams (2014), and Cockrum (2013), the flipped learning involves the move of direct instruction from the group learning space to the individual learning space by using technology and the use of the class time to highlight student-centered learning, interactive learning and higher-level thinking. Based on the concept of flipped learning, the pre-task phase can be moved out of the class time by letting the students do pre-task activities individually in their free time before coming to class in order to save the class time for the during and post-task phases. By this way, teacher can solve the problem of insufficient class time since the content is delivered to individual students outside class by using technology. Also, the problem of the mixed ability class can be solved since the students can learn the content through the technology in their free time and at their own pace. The better students do not have to waste their time learning what they already know, and the lower-level students can spend as much time as they wish preparing themselves for the class. The class time can be spent for doing tasks and other post-task activities, which highlight student-centered learning, interactive learning and higher-level thinking.

Not only can flipped learning help teachers overcome the challenges caused by TBLT, but, vice versa, TBLT can also help teachers minimize the drawbacks posed by the flipped learning model. That is, the flipped learning model requires teachers to make decisions about the best use of their face-to-face time with students to promote student-centered learning, interactive learning and higher-level thinking. However, the model does not provide any principled ways in terms of how to actually make this happen. But, with TBLT, teachers do have some principled guidelines to achieve these goals.

However, since the flipped learning model relies on students to learn the material and prepare themselves before coming to class, the instructional tool must be something motivating, encouraging students to spend their free time with it. Video clips, used commonly as an instructional tool in most flipped classes, do not seem to be an effective tool because when watching videos students receive knowledge in a passive state, making some students feel bored and refuse to watch it before class (Haan, 2011, cited in Cockrum, 2013). Thus, it is necessary to find another tool that is more motivating for the students.

\subsection{A Digital Game: The Third Step to the Solution}

In order to find an effective instructional tool for the flipped learning model, the researcher reviewed a number of literature and related studies on instructional technology. Among many tools suggested, the researcher found that digital games seemed to be a good choice. As believed by many scholars (Lee, 1979; Malone, 1980; de Freitas, 2006; Prensky, 2007, Whitton, 2010; Kapp, 2012), digital games are good for learning because they are motivating and engaging for users. Games also match the needs and learning styles of today's learners. Moreover, they can provide interaction, feedback and meaningful context which are the crucial parts of the learning process. Therefore, in this study a digital game was used, instead of video clips, as an instructional tool in the flipped learning model. 


\subsection{An Integration of Flipped Learning and a Digital Game Into Task-Based Language Teaching: The Solution}

\section{to Overcome the English Oral Communication Difficulties of Nursing Students}

Due to all of the abovementioned reasons, the integration of these three concepts, Task-based language teaching, flipped learning, and a digital game, will not only enhance their advantages but also minimize their drawbacks and the students will be able to improve their English oral communication skill as a result. Thus, this study proposes the task-based instruction using a digital game in a flipped learning environment (TGF) as a solution for overcoming English oral communication difficulties of nursing students.

This study aims to fill a number of gaps from the past research. Firstly, although there have been a number of studies in an EFL context that have investigated the effects of task-based language teaching (TBLT) on English language abilities, there has been no research that has studied the integration of task-based language teaching into flipped learning and digital game-based learning. Secondly, while the studies on the flipped learning have focused on other subjects (e.g. Triantafyllou \& Timcenko, 2015; Clark, 2015; Flynn, 2015; or Kotlik, 2014), there have only been a few studies that have investigated the effects of flipped learning in English education, especially in English for Specific Purposes (ESP) classes. Moreover, most studies on flipped learning have implemented the use of videos as a main content delivery tool (Cockrum, 2014). To date, very little research has been conducted on the application of other types of technology to deliver content in relation to the flipped learning model. Finally, for digital game-based learning, although there have been a number of research studies that have examined the effects of digital games on English language learning in an ESL/EFL context, the digital games used in these studies were of the type of preexisting commercial games, such as the SIMs (Meihami et al., 2013), World of Warcraft (Rama et al, 2012), or Quest Atlantis (Zheng et al., 2009); there has been very little research that has studied the development of digital games in terms of their use and effectiveness in English classes, especially in ESP classes, including English for nursing students.

\subsection{Objective of the Study}

This study aims to investigate the effectiveness of task-based instruction using a digital game in a flipped learning environment (TGF) in improving English oral communication ability of Thai undergraduate nursing students. The research question is, "To what extent does task-based instruction using a digital game in a flipped learning environment (TGF) improve English oral communication of Thai undergraduate nursing students?"

\section{The Development of the Intervention: The Task-Based Instruction Using a Digital Game in a Flipped Learning Environment (TGF)}

The intervention of this study was called "Task-based instruction using a digital game in a flipped learning environment (TGF)". It was developed based on three theoretical frameworks, namely task-based language teaching (TBLT), flipped learning (FL), and digital game-based language learning (DGBLL).

To begin with the TBLT framework, according to Richards and Rodgers (2014), TBLT is an approach based on the use of communicative tasks as the core unit of planning and instructions in language teaching. The main focus of TBLT is on the tasks to be done and language is seen as the instrument necessary to carry them out (Willis, 1996). In this study, the term "task" was defined based on Willis (1996), Nunan (2004), and Ellis (2003) as an activity which involves learners in comprehending, manipulating, producing or interacting in the target language with the intention to convey meaning rather than to manipulate form in order to achieve a communicative or non-linguistic outcome. The TBLT framework used in this study was adapted from Willis (1996), and Ellis (2003) consisting of three main stages, which are Pre-task, During task, and Post-task, as shown in Figure 1. In Pre-task, the teacher helps learners define the topic area, recall and activate words and phrases, provides a model for doing a task, and gives task instructions. In During task, learners are asked to perform the tasks while the teachers observes and encourages from a slight distance. In the last phase, Post-task, the teacher lets learners report how the task was completed, present the products, do focus on forms activities, and repeat the task.

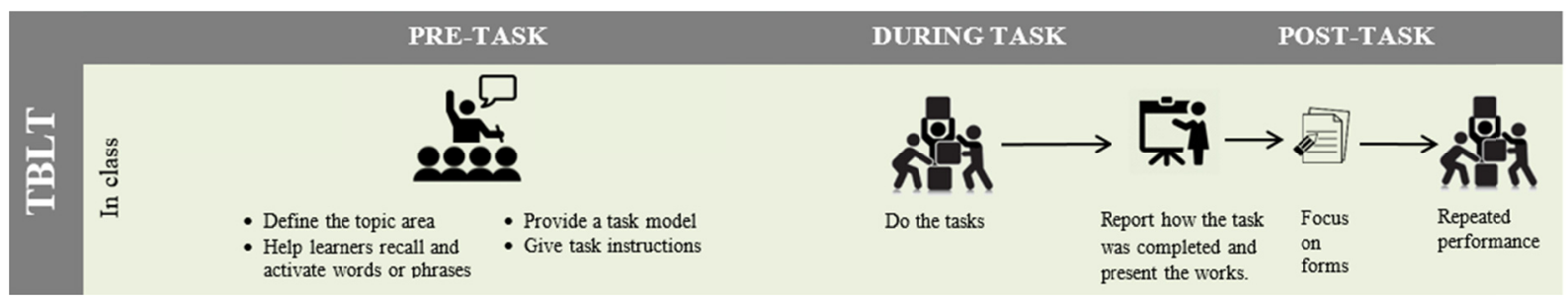

Figure 1. The framework of task-based language teaching (adapted from Willis, 1996 and Ellis, 2003) 
Besides TBLT, flipped learning (FL) is another pedagogical approach that was integrated into the TGF in order to minimize the drawbacks of TBLT as explained earlier. FL, according to Bergmann and Sams (2014), Cockrum (2013), and Morris and Thomasson (2013), is a teaching approach in which the technology is used to deliver the direct instruction to the students individually in their out-of-class time in order that the in-class time will be spent for performing tasks or activities that highlight student-centered learning, interactive learning and higher-level thinking. The FL framework used in this study was adapted from the FL model proposed by Mussallam (2011, cited in Cockrum, 2014). As shown in Figure 2, the model consists of three stages. The first stage is the Explore stage, in which the teacher presents a problem or activity to learners and lets them try to figure it out on their own until they get stuck and need more information. This is done in order to set a purpose for students to do activities in the second stage. Then, in the second stage, the Flip stage, the video providing needed information is presented to learners individually out of the class time. Learners have to watch the video and complete the activity in the first stage. After that, in the Apply stage, which is done in class, learners are assigned to do another activity in which they can apply their knowledge that they have learnt. However, since the use of videos as an instructional tool has some drawbacks as explained earlier, in this study the digital game was used instead.

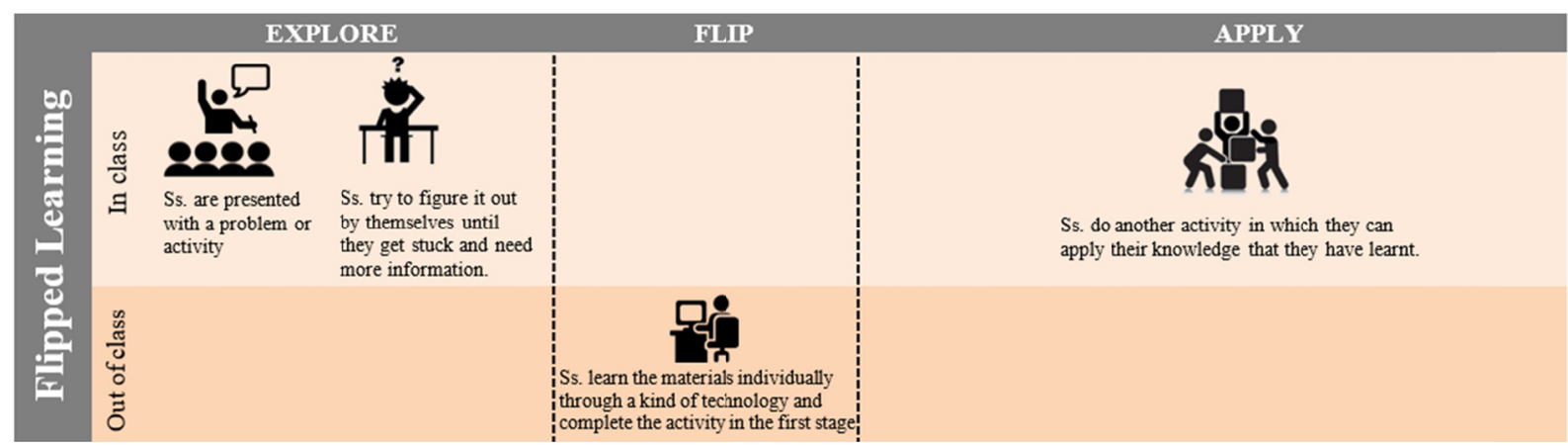

Figure 2. The framework of flipped learning (adapted from Mussallam, 2011)

Since the study used a digital game, instead of videos, as an instructional tool in the flipped learning model, digital game-based learning (DGBLL) was another approach that was integrated into the TGF. A digital game is an activity in which players- via computers, either desktop or laptop computers- engage in an artificial challenge, defined by goals, rules, interactivity, and feedback, that results in a quantifiable outcome (Prensky, 2001; Parllet, 1999; Avedon \& Sutton-Smith, 1971; Crawford, 1984; Suit, 1990; Costikyan, 1994; Abt, 1997; Salen \& Zimmerman, 2004; Kapp et al., 2014; Dempsey et al., 2002; and Whitton, 2010). The DGBLL framework used in this study was adapted from Reinhardt and Sykes (2011). The framework, as illustrated in Figure 3, consists of 4 stages, namely Preview, Explore, Examine, and Extend. In the Preview stage, students answer preview questions about the content of the game either individually or in small groups. Then, in the Explore stage, students learn how to play the game and observe how the game is played. Students also notice and collect game discourses. Then, in the Examine stage, students play the game and do analysis activities focusing on particular language items or strategies for winning the game, then followed by experiential activities which focus on contextualizing the items in interaction such as in discussion, role play or other communicative activities. In the last stage, the Extend stage, students apply their new understandings to create and participate in new discourses through activities focusing primarily on production and presentation skills, present their products to the class, and participate in reflective activities encouraging them to consider thoughtfully about the presentations.

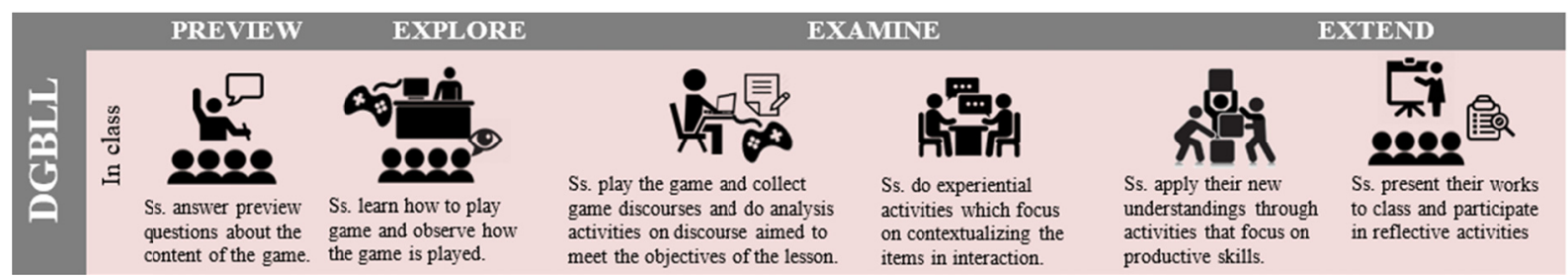

Figure 3. The framework of digital game-based language learning (adapted from Reinhardt \& Sykes, 2011) 
In order to develop the TGF framework, the TBLT, FL, and DGBLL frameworks were compared in order to find out the consistency among the stages in these three frameworks. Then, by using the strengths of one framework to overcome the weaknesses of the other frameworks, all of the three frameworks were integrated to create the TGF framework. Figure 4 illustrates the comparison of the three frameworks.

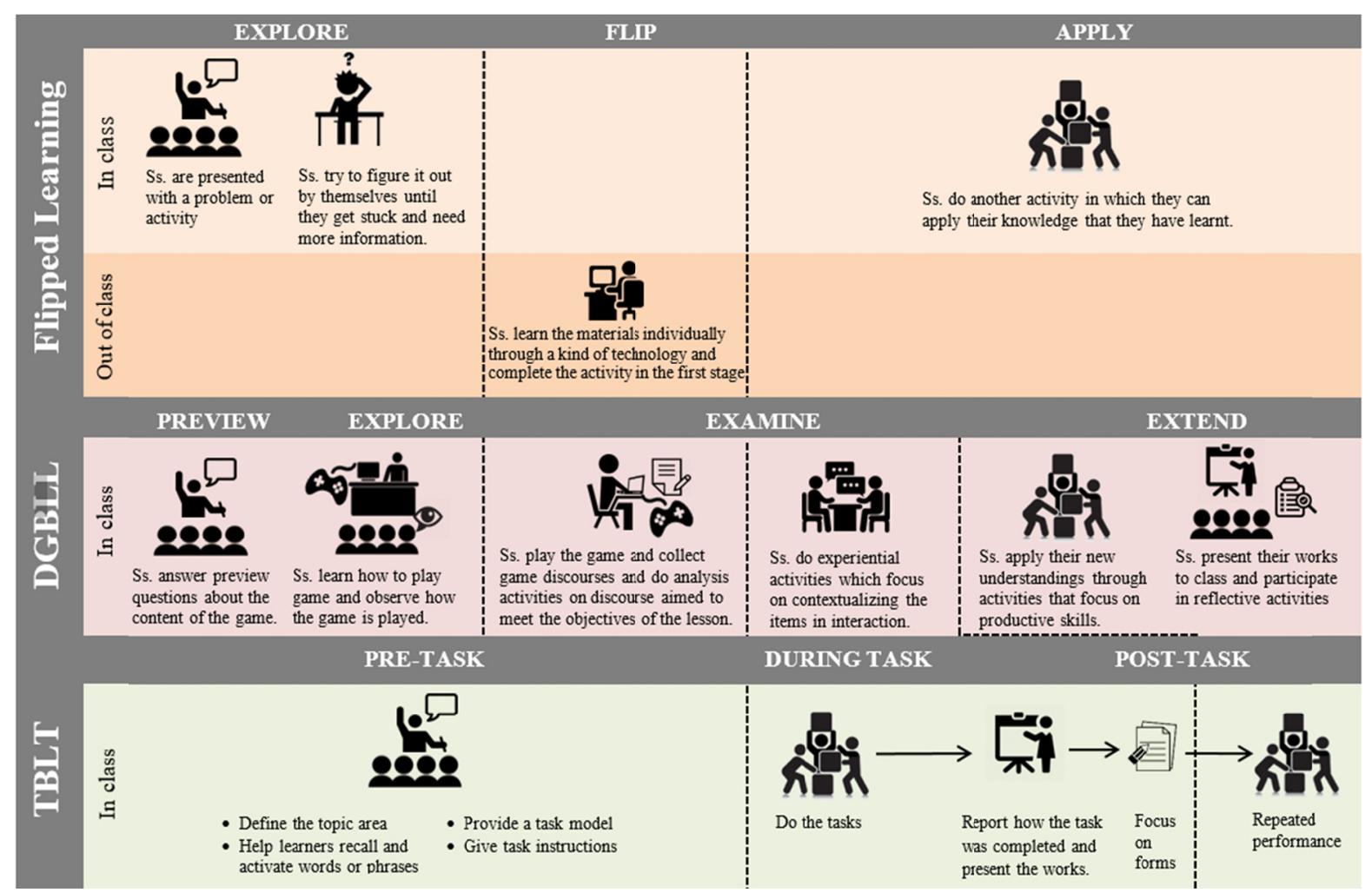

Figure 4. The comparison of the frameworks of flipped learning, digital game-based language learning, and task-based language teaching

Based on the integration of these three frameworks, the instructional framework of the TGF was created. As seen from Figure 5, the TGF framework consisted of 4 main stages, namely Preview, Flip, Task cycle, and Post-task. The Flip stage was conducted out of class, while the other three stages were carried out face-to-face in class. The description of each stage are as follows.

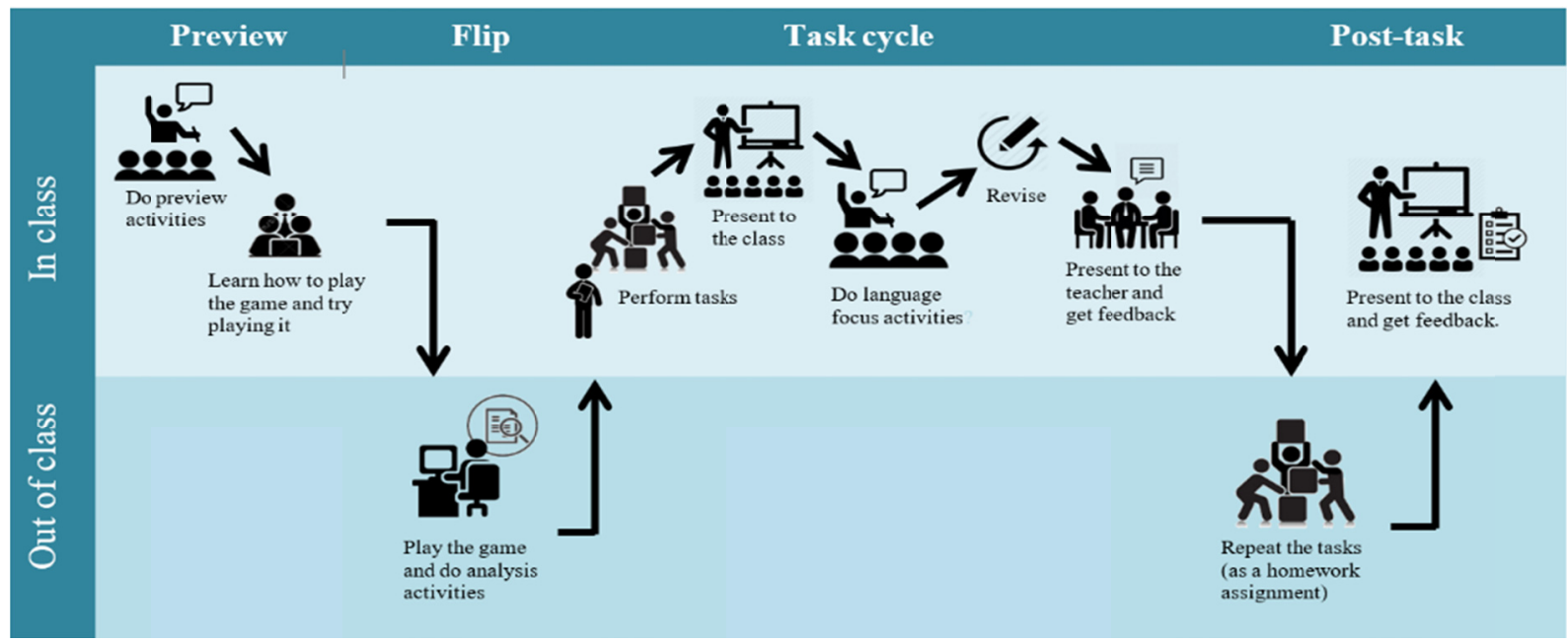

Figure 5. The framework of task-based instruction using a digital game in a flipped learning environment (TGF) 
In the Preview stage, the students were first presented with preview activities or questions about the topic of the lesson. The students were required to do these activities in pairs, or in small groups. These activities aimed to help students define the topic area and activate their background knowledge. It also aimed to set a purpose for the students to play the game. That is, after playing the game, the students were expected to be able to answer all of the preview questions. After the preview activities, the students were introduced to the game and the game analysis activities. The game analysis activities, based on Reinhardt and Sykes (2011), are the activity that focuses on particular language items or strategies for winning the game. The teacher demonstrated how to play the game and explained how to complete the game analysis activities after playing the game. The students had to observe the teacher playing the game first and then were provided with an opportunity to try playing it individually, in pairs or in small groups. This was to ensure that all students understand what to do and how to do it in the next stage. Based on these objectives, the Preview stage took place at the end of previous lesson in every unit.

The second stage, the Flip stage, took place outside of class. The students were required to spend their free time individually playing the game "Cool Nurse" (see Figure 6 for a sample of the game) and completing analysis activities. The objectives of this stage were to let students learn useful words or phrases, give students relevant exposure, provide a task model, and also create interest in doing a task. Since the class met once a week, the students had a whole week, before the next class, to win the game stages and complete the analysis activities, as assigned by the teacher.

The first two stages of the TGF, the Explore and the Flip stages, served as the pre-task activities for the students to prepare themselves for the next stage, the Task cycle stage, in which they had to apply what they had learnt to perform a series of communicative tasks.

The next stage, the Task cycle stage, consisted of 5 steps, all of which took place in class. First, the students were required to perform the tasks either in pairs or in small groups (See Figure 7 for a sample of the in-class task). While the students were performing the tasks, the teacher acted as a facilitator who monitored, observed and encouraged from a slight distance. Second, after the students completed the tasks, they had to present their work to the whole class, to a partner or to a small group in order to get peer feedback. Third, the teacher let the students do language focus activities, involving grammar and structure, vocabulary, and pronunciation. Next, the students had to review their works and revise them. The students then submitted their final work to the teacher to get feedback.

In the last stage of the TGF, the Post-task stage, the students were assigned to repeat the task under the new condition as a homework assignment and present their work to the class. In some units, the students presented their work in front of the class while, in other units, they needed to present their work on FACEBOOK, the social networking website. The rest of the class were asked to give comments to their peers' presentations.
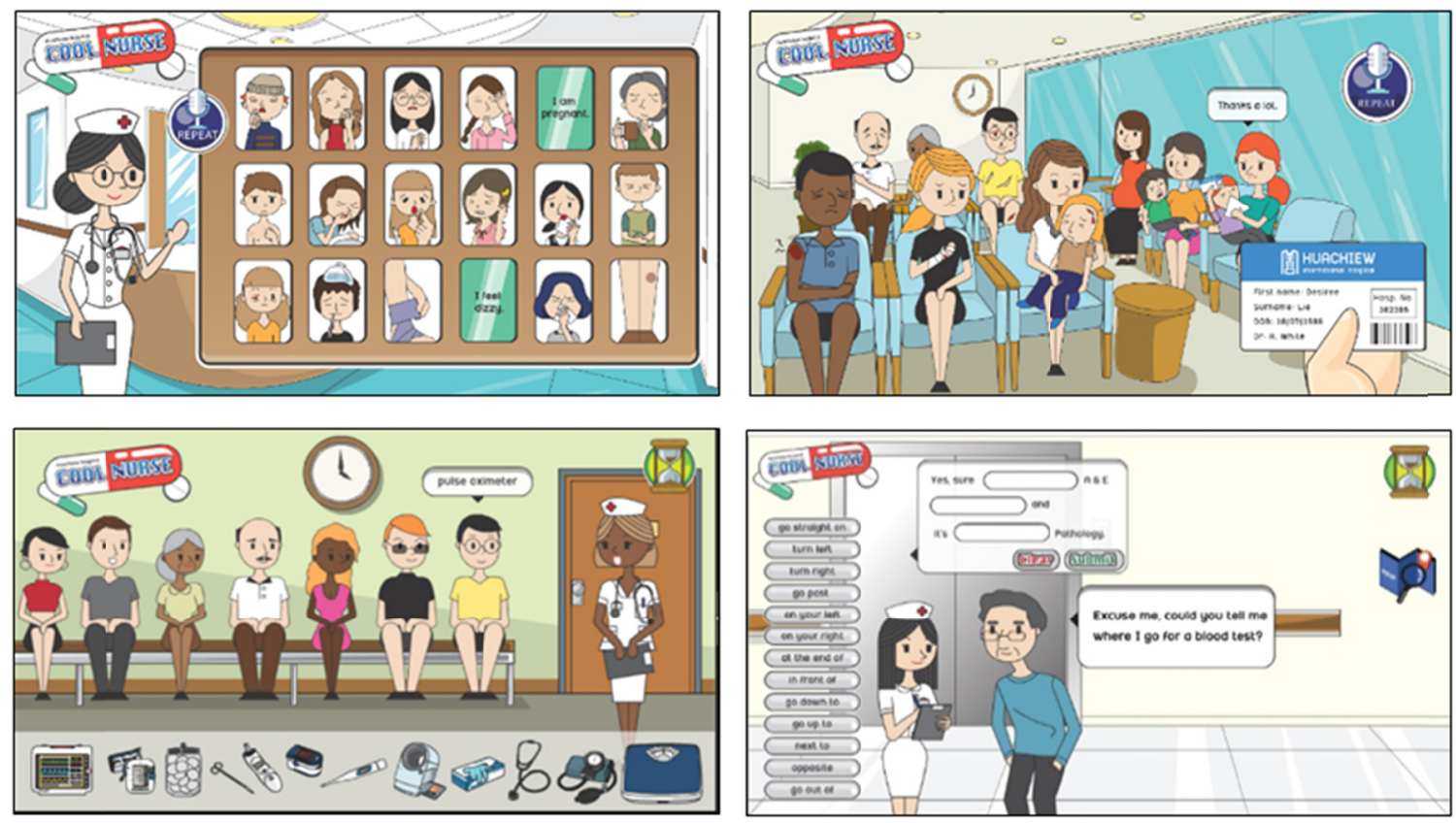

Figure 6. A sample of the digital game, "Cool Nurse" 
Module 1: At the registration desk

Unit 1: Welcoming a patient

\section{TASK 1}

- Students' roles:

\section{Screening a patient}

- Group 1 will play a role of a nurse working in the international hospital.

- Group 2 will play a role of a foreign patient visiting the hospital.

- Role-play situation:

Group 1 students will be the nurses working in an international hospital. Today these nurses are assigned to perform patient screening at the registration office. Each of them has to look for the patient who has symptoms described in their cards and take that patient to see the doctor (the teacher), who will give the medicine to the patient to treat his/her symptoms. Group 2 students will be the foreign patients who visit the hospital today because they are sick, having symptoms described in their cards.

- The goal of the task:

The nurses can take the right patient to the doctor to get the medicine within 15 minutes. To do this, the nurses have to move around to interview different patients about their symptoms until they can find the patient whom they are looking for. The nurses then take that patient to the doctor (the teacher) and describe the patient's symptoms to the doctor so that the doctor can give the medicine to the patient.

Figure 7. A sample of the in-class task

\section{Methodology}

\subsection{Research Design}

This study was an experimental study, which adopted a one-group pretest posttest design. This design was used because it was the most suitable and practical to the context of this study due to two main reasons. First, it enabled the researcher to tell if the participants made progress by comparing their scores at the beginning of the instruction with their scores at the end. Their gain scores could then be used to determine whether or not the participants could improve their oral communication ability after taking the TGF. Second, the nursing students enrolled in the English Listening-Speaking for Nursing Students course were divided into 5 sections, each of which was taught at the same time by five English teachers. The researcher was responsible for one section with 23 students. It was, therefore, impossible to conduct an experiment with two groups of students. This context also made the participants in this study become an intact group since it was also impossible for the researcher to randomly select the samples from the population they represent.

\subsection{Population and Sampling}

The population of this study was 143 second-year undergraduate nursing students of the faculty of Nursing at a private university in Samutprakarn province. Most of them were at lower-intermediate level of English proficiency, as determined by their grade results from a prerequisite course (English for Communication II), which indicated that most of them achieved $\mathrm{C}$ or $\mathrm{C}+$, with an average score of 63.7 out of 100 . Besides, all of them were equivalent in terms of their computer and internet accessibility and experiences in learning through computers. The participants consisted of 23 second-year nursing students, 22 females and 1 male. They were selected by using a convenience sampling method because the researcher had to conduct the study with an intact class. That is, according to their study program, these 23 participants were required to enroll in this course in the first semester of academic year 2017 and the researcher was assigned to teach them. Although the participants were an intact class, they shared the same characteristics with the population of the study in terms of their year of university study, gender, age, level of English proficiency (Their average score on the prerequisite course was 64.3 out of 100), computer and internet accessibility, and experiences in learning through computers.

\subsection{Instruments}

\subsubsection{Instructional Instruments}

The instructional instruments used in this study included the digital game "Cool Nurse", the game manual and lesson plans. 


\subsubsection{The Digital Game}

The digital game used in this study was called "Cool Nurse". It is an online single-player role-playing game for PC, in which the player adopts a role of a new nurse working in an international hospital during a two-month probation period. The player, as a new nurse, is assigned to perform twelve tasks such as checking a patient's personal details, giving directions in the hospital or taking vital signs. The player's performances on these tasks are observed and evaluated by nurse supervisors. As a reward, the player will receive three stars from nurse supervisors after successfully performing each task. The goal of the game is that the player can collect all three stars from each of all twelve tasks in order to pass her probation and get a pay rise.

"Cool Nurse" was developed by the researcher and a team of game developers to use as an instructional tool in the flip stage of the TGF framework, in which the students were asked to spend their free time- out of the scheduled class-time- playing the game individually in order to learn the materials and prepare themselves for the next class. The learning objectives of the game were that, after playing the game, the students should be able to 1) remember new words or phrases related to the course topics, and 2) identify main ideas and specific details from the listening texts related to the course topics.

In this study, the game development process was adapted from Whitton (2010)'s game design model. The game activities were designed based on the digital game design principles proposed by Prensky (2001), Whitton (2010), and Purushotma et al. (2009) as well as English language task design principles suggested by Richards (2006), Nunan (1989), and Nation and Newton (2009). However, some game activities were adapted from English commercial textbooks, namely Cambridge English for Nursing Pre-intermediate (Allum \& McGarr, 2012), English for Nursing 1 (Wright et al., 2012), and English for Nursing 2 (Wright et al., 2011).

Before being used in the actual study, "Cool Nurse" had undergone several modifications in both design and game content based on the feedback obtained from the playtesting by 4 groups of playtesters, namely nursing students, nursing teachers, English teachers, and programmers. The game scripts were proofread by a native English speaker to ensure language accuracy. Besides, the game was also validated and evaluated by three experts and was adjusted according to their suggestions.

\subsubsection{The Game Manual}

In this study, the game manual was designed to be used mainly in the Explore and Flip stages. Both Thai and English were provided in the manual to ensure that all of the students could understand the manual very clearly. The organization of the game manual was in consistent with the organization of the game. That is, the manual starts with the introduction, the information and activities related to each game stage, and the conclusion part.

The main part of the game manual consists of the information and activities related to each game stage. There are 6 units. Each unit consists of 4 parts. Part 1: Try thinking first includes preview activities, which the students are assigned to do in the Explore stage of the TGF framework. Part 2: Show off your skills is the game instructions, explaining how to play each game stage and also the criteria to complete it. Part 3: "Reflect on your work" involves a debriefing and reflective activity, in which the students are asked about their experience in completing the game stage There are also exercises to test whether or not the students remember what they had learnt from the game. Answer keys are provided for the students to check the answers by themselves. Part 4 is called "Assess Yourself". This part is for the students to evaluate their own progress.

The game manual was evaluated and validated by three experts and was adjusted according to their suggestions before being used in the actual study.

\subsubsection{Lesson Plans}

In this study, 6 lesson plans were designed based on the TGF framework to cover 6 units, namely Unit 1: Welcoming a patient, Unit 2: Asking for a patient's details, Unit 3: Giving directions in the hospital, Unit 4: Describing vital signs equipment, Unit 5: Taking vital signs, and Unit 6: Describing vital signs readings. Each lesson plan was designed for one teaching week which was a three-hour class session. The tasks and activities in each lesson were designed based on Willis (1996), Nunan (2004), Thornbury (2005), Ellis (2009), Nation and Newton (2009), and Willis and Willis (2011). Each of the six lesson plans consisted of the title of a unit, objectives, language focus, time allocated, tasks and activities, teaching steps, and instructional materials such as role cards, handouts, or worksheets.

All lesson plans were evaluated and validated by three experts and were adjusted according to their suggestions before being used in the actual study. 


\subsubsection{Research Instruments}

Research instruments in the present study were the English oral communication test and the rating scale for assessing English oral communication ability.

\subsubsection{The English Oral Communication Test}

The English communication test was used to measure the students' English oral communication ability before and after learning through the TGF. The test was developed by the researcher based on the course objectives and the content taught in the TGF. The test was a direct test type, a guided role play activity. The participants participated in a structured one-to-one interaction between examiner and student, which lasted approximately 15 minutes. The participants assumed a role of a nurse working in an international hospital while the examiner (a native English speaker) played a role of a foreign patient. The participants were provided with a speaking prompt, which explained the situation and tasks required to do. The examiner also had a prompt, consisting of a script and detailed information to use in the role play. When doing a role play, the examiner followed the script and answered the students' questions by using the information in his card. The test was designed to cover the topics taught in the course, namely greeting a patient and offering help, introducing yourself, asking about symptoms and injuries, asking for a patient's personal details, giving directions to hospital departments and facilities, taking vital signs, and describing readings.

\subsubsection{The Analytic Rating Scale for Assessing English Oral Communication Ability}

The rating scale was adapted from Speaking Rating Scale of Michigan English Test (MET, 2013), Speaking Assessment Criteria of Occupational English Test (OET, public version, 2016), and Speaking Assessment Criteria of the Aptis test (2015). The scale comprised four main components, which were Task achievement and language resources (including 7 subcomponents, namely Greeting and offering help, introducing yourself, asking about symptoms and injuries, asking for personal details, giving directions, taking vital signs, and describing readings), listening comprehension, pronunciation, and fluency. The students' performances on each component were divided into 5 levels (1-5), the descriptions of which were provided on the scale. The raters then rated the student's performance by determining how well the performance fit the description of each performance level (1-5). Since the scale consisted of 10 components ( 3 components and 7 subcomponents), the total score of the test was, therefore, 50 points.

To ensure the content validity, the test and the rating scale were evaluated and validated by three experts and were adjusted according to their suggestions.

Besides, the pilot of both instructional and research instruments was conducted for three weeks. The participants in the pilot study were 12 second-year nursing students, who were representatives of the population but were not participants of the main study. The instruments were adjusted according to their feedback. Then, these adjusted instruments were used in the main study.

\subsection{Data Collection}

The data collection was conducted in the first semester of academic year 2017. The time sequence and procedure of data collection are described in Table 1.

Table 1. Data collection

\begin{tabular}{|c|c|c|}
\hline Week & Date & Data collection Procedures \\
\hline 1 & 15 Aug 17 & Administer the pre-test to the participants. \\
\hline 2 & 23 Aug 17 & $\begin{array}{l}\text { In class (3 hours) } \\
\text { - Introduce the TGF and all the instructional materials } \\
\text { - Conduct the technical training for the game "Cool Nurse" } \\
\text { - Deliver unit } 1 \text { : Welcoming a patient (Preview stage) } \\
\text { Out of class ( } 1 \text { week) } \\
\text { - } \quad \text { Flip stage: complete stages } 1-3 \text { of the game and do analysis activities }\end{array}$ \\
\hline 3 & 30 Aug 17 & $\frac{\text { In class ( } 3 \text { hours) }}{\text { - } \quad \text { Deliver unit } 1 \text { : Welcoming a patient (Task Cycle and Post-task stages) }}$ \\
\hline
\end{tabular}


- Deliver unit 2: Asking for a patient's details (Preview stage)

Out of class (1 week)

- Flip stage: complete Stage 4-5 of the game and do analysis activities

4 6 Sep $17 \quad$ In class (3 hours)

- Deliver unit 2: Asking for a patient's details (Task Cycle and Post-task stages)

- Deliver unit 3: Giving directions in the hospital (Preview stage)

Out of class (1 week)

- Flip stage: complete Stage 6-7 of the game and do analysis activities 13 Sep 17 In class (3 hours)

- Deliver unit 3: Giving directions in the hospital (Task Cycle and Post-task stages)

- Wrap-up: units 1-3

- Deliver unit 4: Vital sign equipment (Preview stage)

Out of class (1 week)

- Flip stage: complete Stage 8-10 of the game and do analysis activities

- Deliver unit 4: Vital sign equipment (Task Cycle and Post-task stages)

- Deliver unit 5: Taking vital signs (Preview stage)

Out of class (1 week)

- Flip stage: complete Stage 11 of the game and do analysis activities

- Deliver unit 5: Taking vital signs (Task Cycle and Post-task stages)

- Deliver unit 6: Describing vital sign readings (Preview stage)

Out of class (1 week)

- Flip stage: complete Stage 12 of the game and do analysis activities

- Deliver unit 6: Describing vital sign readings

- Wrap-up: units 4-6

1125 Oct 17 Administer the post-test to the participants.

\subsection{Data Analysis}

To investigate the effectiveness of the TGF in improving the students' English oral communication ability, all of the 23 participants were pre-tested and post-tested for their oral communication ability. Each participant's oral communication performance was video-recorded and rated by three raters (the researcher, the native-English English teacher, and the native-Thai English teacher) using the rating scale designed for this study. Three sets of scores from three raters were combined and divided by three to find out the mean score for each participant. Then, to analyze the participants' pre- and post-test mean scores, the Statistical Package for the Social Sciences (SPSS) was used to compute descriptive statistics and inferential statistics. For descriptive statistics, the participants' scores on pre- and post-test were calculated for mean $(\overline{\mathrm{X}})$, and standard deviations (SD). The preand post-test mean scores were then compared to see whether the participants could increase their test scores after taking the TGF or not. For inferential statistics, paired-samples t-test or dependent-samples t-test was used to test whether the post-test mean score was statistically significantly higher than the pre-test mean score at the level of 0.05 or not. Additionally, Cohen's d was calculated to determine whether the effect size of the difference in the means was small $(d=0.20-0.40)$, moderate $(d=0.50-0.70)$ or large $(d \geq 0.80)$. 


\section{Results and Findings}

The results from the pre-test and post-test, as shown in Figure 8, revealed that all of the participants scored better on their post-test. Out of 50, the participants' pre-test scores range from 15 to 34 while their post-test scores range from 25 to 44 .

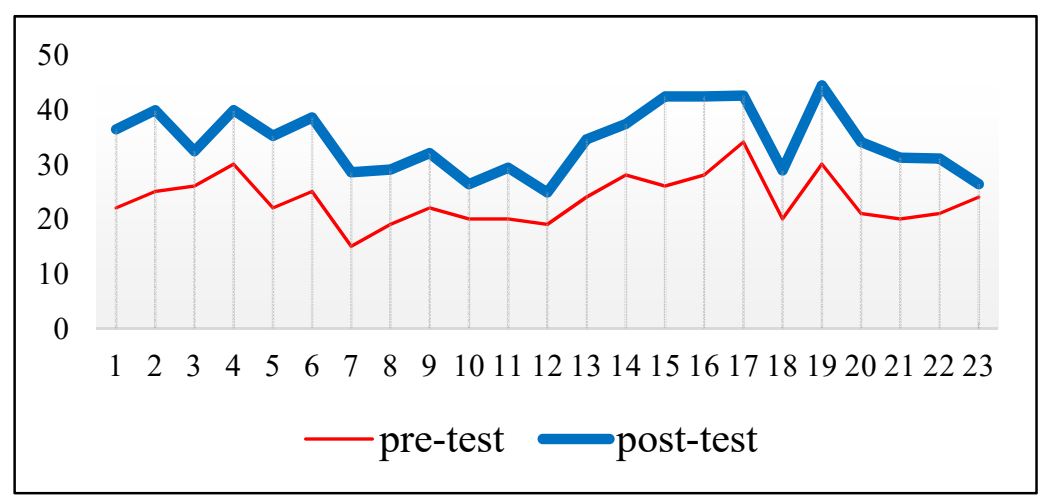

Figure 8. Participants' mean scores on the pre- and post-test

Table 2 also shows that the participants' post-test mean score (34.17) was higher than their pre-test mean score (23.52). These findings indicate that after participating in the TGF, the participants made an improvement in their English oral communication ability.

Table 2. The participants' pre-test and post-test mean scores

\begin{tabular}{lll}
\hline English oral communication test & Mean $(\overline{\mathrm{X}})$ & SD. \\
\hline Pre-test & 23.52 & 4.440 \\
Post-test & 34.17 & 5.859 \\
\hline
\end{tabular}

Additionally, Paired Sample t-test was used to calculate whether or not the difference in the participants' pre-test and post-test mean scores was statistically significant. Then Cohen's $d$ was calculated to determine the effect size of the difference in the means. The findings are presented in Table 3.

Table 3. Paired-Samples t-test of the pre-test and post-test mean scores

\begin{tabular}{|c|c|c|c|c|c|c|c|c|}
\hline \multirow{3}{*}{$\begin{array}{l}\text { English oral } \\
\text { communication test }\end{array}$} & \multicolumn{4}{|c|}{ Paired Differences } & \multirow{3}{*}{$\mathrm{t}$} & \multirow{3}{*}{$\mathrm{df}$} & \multirow{3}{*}{$\begin{array}{l}\text { Sig } \\
\text { (2-tailed) }\end{array}$} & \multirow{3}{*}{ d } \\
\hline & \multirow[t]{2}{*}{$\overline{\mathrm{X}}$} & \multirow[t]{2}{*}{ SD } & $\begin{array}{l}95 \% \\
\text { Interval } \\
\text { Difference }\end{array}$ & $\begin{array}{l}\text { Confidence } \\
\text { of the }\end{array}$ & & & & \\
\hline & & & Lower & Upper & & & & \\
\hline Pretest - Posttest & 10.652 & 3.485 & 12.159 & 9.145 & $14.658^{*}$ & 22 & .000 & 3.057 \\
\hline
\end{tabular}

$* \mathrm{p}<0.05$.

From Table 3, the t-value of 14.658 from Paired-Samples t-test indicates that the participants' average post-test score in the English oral communication test was statistically significantly higher than their average pre-test score $(p<0.05)$. Further, the Cohen's effect size value $(d=3.057)$ reveals a very large effect size of the difference in the means, which indicates that the difference between the participants' pre-test and post-test means was also practically significant.

For further information, Table 4 shows the participants' pre-test and post-test mean scores on each component, namely Task achievement and language resources (greeting a patient and offering help, introducing yourself, asking about symptoms and injuries, asking for a patient's personal details, giving directions to hospital 
departments and facilities, taking vital signs, and describing readings), listening comprehension, pronunciation, and fluency.

Table 4. The participants' pre-test and post-test mean scores on each component

\begin{tabular}{llllll}
\hline English oral communication components & $\begin{array}{l}\text { Pre-test } \\
\text { Mean }\end{array}$ & SD & $\begin{array}{l}\text { Post-test } \\
\text { Mean }\end{array}$ & SD & Gain score \\
\hline 1. Task achievement and language resources & & & & & \\
1.1 Greeting a patient and offering help & 2.78 & 0.671 & 4.48 & 0.790 & +1.70 \\
1.2 Introducing yourself & 2.65 & 0.775 & 4.00 & 1.595 & +1.35 \\
1.2 Asking about symptoms and injuries & 1.83 & 0.717 & 3.35 & 0.982 & +1.52 \\
1.4 Asking for a patient's details & 2.48 & 0.790 & 3.22 & 0.736 & +0.74 \\
1.5 Giving directions & 1.65 & 0.935 & 3.26 & 0.864 & +1.61 \\
1.6 Taking vital signs & 2.09 & 0.793 & 3.13 & 0.968 & +1.04 \\
1.7 Describing readings & 2.00 & 0.798 & 3.13 & 0.869 & +1.13 \\
2. Listening comprehension & 3.13 & 0.344 & 3.70 & 0.470 & +0.57 \\
3. Pronunciation & 2.91 & 0.515 & 3.22 & 0.518 & +0.30 \\
4. Fluency & 2.91 & 0.733 & 3.70 & 0.822 & +0.78 \\
\hline
\end{tabular}

It can be seen from Table 4 that the participants' post-test mean scores on all ten components were higher than their pre-test mean scores. "Greeting a patient and offering help" was the component that the participants could make the highest gain score, at 1.70. The second and third highest gain scores were the component "Giving directions" at 1.61 and the component "Asking about symptoms" at 1.52 respectively. The component that the participants made the lowest gain score at 0.30 was "Pronunciation".

In addition, Paired-Samples t-test was also used to test if there was a significant difference between pre-test and post-test mean scores on each of the ten components. Cohen's $d$ was, further, calculated to determine the effect size of the difference in each component means. The findings are shown in Table 5.

The findings in Table 5 indicate that the participants' post-test mean scores on all components were statistically significantly higher than their pre-test mean scores $(\mathrm{p}<0.05)$. Additionally, Cohen's $d$ values reveal large to very large effect size of the differences in the means on every component, except pronunciation, of which the $\mathrm{d}$ value indicates moderate effect size. These high $d$ values, then, indicate a practically significant difference in the participants' pre-test and post-test mean scores on all components.

Hence, it can be concluded that after learning through the TGF, the participants improved their English oral communication ability in all components, namely Task achievement and language resources, Listening comprehension, Pronunciation, and Fluency.

Table 5. Paired-Samples t-test of the pre-test and post-test mean scores on each component

\begin{tabular}{|c|c|c|c|c|c|c|c|c|}
\hline \multirow{3}{*}{$\begin{array}{l}\text { English oral communication } \\
\text { components }\end{array}$} & \multicolumn{4}{|c|}{ Paired Differences } & \multirow{3}{*}{$\mathrm{t}$} & \multirow{3}{*}{ df } & \multirow{3}{*}{$\begin{array}{l}\text { Sig } \\
\text { (2-tailed) }\end{array}$} & \multirow{3}{*}{ d } \\
\hline & \multirow[t]{2}{*}{$\overline{\mathrm{X}}$} & \multirow[t]{2}{*}{ SD. } & \multicolumn{2}{|c|}{$\begin{array}{l}95 \% \text { Confidence } \\
\text { Interval of the } \\
\text { Difference }\end{array}$} & & & & \\
\hline & & & Lower & Upper & & & & \\
\hline $\begin{array}{l}\text { 1. Greet a patient } \\
\text { Pretest - Posttest }\end{array}$ & 1.696 & .765 & 2.026 & 1.365 & $10.632 *$ & 22 & .000 & 2.217 \\
\hline $\begin{array}{l}\text { 2. Introduce yourself } \\
\text { Pretest - Posttest }\end{array}$ & 1.348 & 1.526 & 2.008 & .688 & $4.236^{*}$ & 22 & .000 & 0.883 \\
\hline 3. Ask about symptoms & 1.522 & .898 & 1.910 & 1.133 & $8.127^{*}$ & 22 & .000 & 1.695 \\
\hline
\end{tabular}


Pretest - Posttest

\section{Ask for details}

Pretest - Posttest

\section{Give directions}

Pretest - Posttest

\section{Take vital signs}

Pretest - Posttest

\section{Describe readings}

Pretest - Posttest

\section{Comprehension}

Pretest - Posttest

9. Pronunciation

Pretest - Posttest

\section{Fluency}

Pretest - Posttest

$$
.739
$$

.752

1.609

1.118

1.043

.976

1.466

.621

$5.127 *$

22

.000

1.069

1.130

.968

1.549

.712

$5.601 *$

22

.000

1.167

.565

.507

.784

.346

$5.348^{*}$

22

.000

1.114

.304

.470

.508

.101

$3.102 *$

22

.005

0.647

.783

.671

1.073

.492

$5.591 *$

22

.000

1.167

\section{Discussion}

This study demonstrated that the students significantly improved their English oral communication ability after receiving the TGF, as shown by their average post-test score, which was 10.65 points higher than their average pre-test score. This part then discusses the key factors contributing to the success of the TGF in improving overall oral communication ability of the students.

\subsection{The Factors Contributing to the Success of the TGF}

The success of the TGF in improving overall oral communication ability of the students was due to the fact that the integration of the three language learning approaches, namely task-based language teaching, digital game-based language learning, and flipped learning, provided effective learning opportunities for the students to develop their English oral communication ability. These opportunities are as follows.

1). An opportunity to activate and develop background knowledge on the topic before performing the speaking tasks

In this study, the integration of flipped learning approach into the TGF helped the teacher gain 'an extra time' in class, so the teacher could spend 15-20 minutes at the end of the class to prepare the students for the next class by letting them do preview activities to activate and develop their background knowledge on the topic. This study showed that, by doing this, the students were likely to perform the speaking tasks and activities better. As this course was an ESP course designed for nursing students, the in-class tasks and activities were then designed based on the situations that the students would face in their future professional world. However, at the time of the course, the students still had very little experience of those situations. Besides, the students were in the first semester of their second year in the nursing program so, prior to this course, they had taken only general courses. Hence, it was likely that the students might not have adequate background knowledge on the topics taught in the course. A lack of adequate background knowledge might be one of the reasons causing the students difficulties in communicating with others in English. Since, according to Levelt (1989, cited in Burns, 2016), speech production begins with conceptual preparation, which involves a speaker's selection of a topic or information from his own background knowledge to provide relevant and appropriate responses to the ongoing interaction, a speaker who lack background knowledge would find it difficult to respond in rapid interactive speech. Additionally, taking time to help the students activate and develop their background knowledge before asking them to perform a task seemed to increase their self-confidence and make them more willing to participate actively in the speaking tasks, which led to their improvement in their oral communication ability, as a consequence. This was consistent with Macintyre et al. (1998), who stated that the knowledge of the topic played a crucial role in increasing the person's self-confidence to communicate in a foreign language and the familiarity with the topic also made a person use a language more easily. Besides, this study also confirmed the findings of a number of previous studies (Matsuoka \& 
Evans, 2005; Kang, 2005; Pattapong, 2010; Xie, 2011; and Zarrinabadi, 2014), which indicated a positive effect of background knowledge and the familiarity with the topic on making the students feel confident and be more willing to communicate in a foreign language.

2). An opportunity to practice some key language features (vocabulary, grammar, and pronunciation) in the out-of-class time before performing the speaking tasks

As the study integrated flipped learning approach into task-based language teaching, at the Flip stage in the TGF, the students were required to spend their free time- out of the class time- playing the digital game, "Cool Nurse" and doing the analysis activities in the game manual in order to study the materials including vocabulary, grammar, and pronunciation, to prepare themselves before coming to class. The study showed that the students benefited from this opportunity in two ways. Firstly, they could learn at their own pace and in their own preferred ways. According to many scholars like Johnson (1996), Bailey (2003), Goh (2007), and Burns (2016), due to numerous cognitive demands placed on speakers, in order to develop a language learner to be a competent speaker, it is necessary that language learners should be provided with linguistic support before being asked to perform a speaking task. However, Ellis (2003) and Willis (1996) pointed out that it is relatively challenging for the teacher to provide the linguistic support that is sufficient and appropriate to scaffold the learning process of each individual student. However, at the Flip stage of the TGF, each individual student could study the materials at their own pace, so the students could decide by themselves on how much time they need for learning and practicing the target language features in order to make themselves ready to perform the task. They could also decide by themselves when or how to study. Since in the TGF the student' individual needs were catered for, each student would likely to gain benefit from the support provided in the TGF. This, therefore, might be the reason why the students could develop their oral communication ability. Secondly, it could also be observed that the students gained more confidence to participate actively in the in-class speaking tasks. This finding were in line with a number of studies which implemented the flipped learning in EFL classrooms such as Gibson, \& Sodeman (2014); Köroğlu \& Çakır (2017), Chen Hsieh et al. (2017), Teng (2018), and Quyên \& Lợi (2018), which also revealed the benefits of pre-class activities in making students participate more actively in the English speaking class. This was because preparing themselves before coming to class could help them lower the level of their language classroom anxiety and raise the degree of their self-perceived oral communication ability. The lower level of language classroom anxiety and the higher degree of self-perceived oral communication ability, then, made them feel more willing to communicate in English and participate more actively in the in-class speaking tasks and activities (Horwitz et al., 1986; Young, 1990).

\section{3). An opportunity to learn the language content through the digital game}

In the TGF, the students benefited from the opportunity to study the materials through playing the digital game in two ways. First, the students were presented with the input that facilitated language acquisition. Krashen (1989, cited in Saengboon, 2004, p. 14) described the characteristics of the input that facilitates language acquisition as, "To optimize acquisition, Krashen further argues, the input should be comprehensible, relevant, interesting, sufficient, and presented in a situation that encourages a low filter setting (i.e. encouraging positive attitudinal factors)." It seemed that the input provided in the game matched this description. To clarify, the game "Cool Nurse" was designed especially for the students in the study who were low to lower-intermediate level language learners. The listening text in the game was then adjusted through speech simplification and elaboration in order to make them comprehensible to the students as much as possible. Next, the language input was also presented through the story of the game which was written especially for the students in the present study, making the input become relevant and interesting to the students. Through playing the game, the students were provided with a lot of exposure to the targeted input. That is, it was presented to the students several times and also in a variety of context throughout the game. Lastly, the most obvious benefit of using the digital game to present the target language input was that the students were exposed to the input in a relaxed and enjoyable way, in which their affective filter was relatively low. Thus, it can be concluded that the exposure of the language input through the digital game, Cool Nurse, was likely to promote the students' language acquisition. Besides, through playing the game, the students were likely to memorize vocabulary better. This was also in line with a number of previous studies (e.g. Yip \& Kwan, 2006; Aghlara \& Tamjid, 2011; AlShaiji, 2015; Yen et al., 2016) that indicated the positive effects of digital games on English vocabulary recognition and retention. This might be due to the following reasons; 1) The game, as the combination of audiovisual media, could provide the students with a learning experience that was more realistic, encouraging the students to use their senses, namely sight, sound, and touch, to learn the target language, which, based on Dale's Cone of Experience (1969, cited in Lee \& Reeves, 2007), was a rich and memorable experience that was effective in promoting permanent learning. 2) The game also offered the students a chance to learn vocabulary through both visual and audio modalities, which was believed, based on Paivio's 
Dual Coding theory (1990), to increase the students' ability to memorize words. 3) Playing the game also provided the students with the frequent and repetitive exposure of the target words, which was believed as a key factor contributing to language acquisition (Loschky, 1994; Barcroft, 2015).

\section{4). An opportunity to practice speaking English through performing the in-class tasks and activities}

The integration of flipped learning approach into task-based language teaching in this study provided the teacher with an 'extra' class time. Since before coming to class the students had already been presented with all of the target features through the digital game "Cool Nurse", the whole 3-hour class time could then be spent for letting the students practice using the target features through performing a series of tasks and activities. Providing the students with a large amount of communicative practice seemed to help them improve their oral communication ability. The importance of practice to the acquisition of second language is also affirmed by a number of scholars such as McLaughlin and Heredia (1996), Anderson (2000), Nation and Newton (2009), and Dykeyser (2010, 2015). Moreover, a variety of techniques, including information gap, guessing, search, matching, or role play, were used to design the tasks and activities in order to make the target features become 'essential'. By making the target structures become an essential tool, the students were likely to pay their attention to those structures and they were forced to 'notice' the target structures and also assist the students to 'notice-the-gap' in their interlanguages, which according to Schmidt (1990, in Ellis, 2009), is a prerequisite for learning to take place. In addition to the design of the activities, the amount and the sequence of the activities in the class was also a key factor leading to the students' improvement. In each lesson, the students were asked to perform not just only one task but a series of tasks and activities. Mostly, they were asked to perform a pair work first, then a small group or a whole class activity. As most of the students in this study tended to be reticent to speak English with others due to their shyness or fear of making mistakes, letting them work in pairs first made them feel more relaxed and more willing to speak English. The use of pair works was also supported by the findings of the studies conducted by Young (1990) and Noom-ura (2008) which suggested that it could help reduce learners' anxiety in L2 speaking class and could increase their willingness to communicate in L2. After completing a pair work, the students were asked to perform a few more activities in a larger-group settings- from a small-group to a whole-class activity while speaking in front of the class, which was the most anxiety-provoking activity (Young, 1990), was done lastly at the end of each lesson. In this study, by observing the students doing the activities in class, the researcher found that in the first activity of each lesson, most students did not talk much and often looked at their notes to find the words or expressions to speak with their partners. It was also observed that instead of 'speaking', some students 'read' the sentences from their notes to their partners. However, when doing the subsequent activities, the students were found more relaxed and more confident to speak English with their classmates. They tried to talk to each other more frequently and also tried harder to speak by using words or expressions from their own memories without looking at their notes. Additionally, it was also observed that, while the students were performing the activities in pairs or in small groups, they helped one another to produce the target structures in a variety of ways. Firstly, it could be observed that the students directly asked for, and received, assistance from each other. Besides, it was also found that when the students sensed the difficulties their partners were facing when producing utterances- such as pausing or looking at their notes to find the words, the students offered assistance such as continuing their partners' unfinished utterances or offering correct words and forms to their partners. Their partners then used the suggested words to continue their utterances. This kind of assistance that the students provided to one another seemed to facilitate the students' language learning process, which was also affirmed by the previous studies of Ohta (1995), Swain and Lapkin (1998), and Foster and Ohta (2005).

\section{5). An opportunity to explicitly focus on form}

In this study, after the students had completed all of the in-class speaking tasks and activities, they were required to do language-focused activities. In each lesson, there were two types of language-focused activities. The first type was an activity that required the students to work in pairs or in small groups to write a role-play script related to the previous speaking tasks and presented it to the class. During the presentation, the teacher provided explicit feedback on the students' use of the targeted structure using techniques like recasts or explicit correction. Then, the students were required to practice the target form through grammar, vocabulary, and pronunciation exercises and drills. After that, they were required to revise and edit their work (a role-play script) and submitted the final work to the teacher to get more feedback. It was likely that the provision of the explicit form-focused instruction through these activities was one of the key factors contributing to the improvement of the students in their oral communication ability especially in their improvement of grammatical, lexical, and phonological accuracy. This finding was in line with Lightbown and Spada (2008) who believed that form-focus instruction is necessary for EFL learners since it helps them make more efficient use of their limited exposure to the sounds, words, and sentences of the language they are learning. Willis (1996), also provided support for explicit form-focused 
instruction by saying that it can help learners notice specific features of the target language and then as a result it speeds up the rate of language development and also raises the ultimate level of the learners' attainment. In fact, Willis, as well as Skehan (1998) emphasized that form-focused instruction is one of the necessary components of a task-based lesson to ensure that learners will not develop fluency at the expense of accuracy. Moreover, the findings of a number of empirical studies such as Spada \& Lightbown (1993), Doughty \& Varela (1998), Norris \& Ortega (2000), and Lyster (2004) also provided an evidence showing the benefit of an explicit form-focused instruction in helping EFL learners use their L2 with greater accuracy.

\section{Conclusion}

As a means to overcome English oral communication difficulties of nursing students, the task-based instruction using a digital game in a flipped learning environment (TGF) was developed by integrating three language learning approaches, namely task-based language teaching, flipped learning, and digital game-based language learning. The findings of this study showed that the students had improved their English oral communication ability after receiving the TGF. The reason might lie in the fact that the integration of these three learning approaches could create effective language learning opportunities for the students. Based on these findings, it is recommended that language teachers should let students practice the target language before coming to class since it facilitates their language learning in two main ways First, it allows the students to learn at their own pace and in their own preferred ways. Second, it helps students reduce their language anxiety and increase their self-perceived oral communication ability, making them feel more willing to communicate with others in English when performing the speaking tasks. Moreover, teachers can cater for the students' individual needs, thus, being able to minimize the problems of mixed-ability large class. This study also suggests the use of a digital game as a self-study tool since it promotes language learning in a number of ways. Besides, it is highly recommended that teachers should let students practice speaking through performing a series of communicative tasks that were designed to make target features become an essential tool for students to achieve the task outcome. Lastly, the study also suggests the provision of an opportunity for students to explicitly focus on form.

Although the present study showed the effectiveness of the TGF in improving the students' oral communication ability, it was conducted with only one group of a small number of participants and the effectiveness of the TGF was investigated by using only the quantitative results from the pre- and post-test. It is then recommended that future studies could be conducted with a larger number of participants and qualitative data collection and analysis should be employed to yield more in-depth data. Moreover, it is also worth to explore the participants' opinions toward the TGF.

\section{References}

Abt, C. C. (1987). Serious games. University Press of America.

Aghlara, L., \& Tamjid, N. H. (2011). The effect of digital games on Iranian children's vocabulary retention in foreign language acquisition. Procedia-Social and Behavioral Sciences, 29, 552-560. https://doi.org/ 10.1016/j.sbspro.2011.11.275

Alharby, M. (2005). ESP Target Situation Needs Analysis: The English Language Communicative Needs as perceived by Health Professionals in the Riyadh Area. Retrieved from http://faculty.ksu.edu.sa/majed/ Documents/alharby_majid_200505_phd.pdf

Allum, V., \& McGarr, P. (2012). Cambridge English for nursing. Ernst Klett Sprachen.

AlShaiji, O. A. (2015). Video games promote Saudi children's English vocabulary retention. Education, 136(2), 123-132.

Anderson, J. R. (2000). Learning and memory: An integrated approach. John Wiley \& Sons Inc.

Amornvivat, S. (2012). Medical tourism under threat. Bangkok Post, 20.

Avedon, E. M., \& Sutton-Smith, B. (1971). The study of games. John Wiley \& Sons.

Bailey, K. M. (2003). Speaking. Practical English language teaching, 47-66.

Barcroft, J. (2015). Vocabulary in language teaching. Routledge

Bergmann, J., \& Sams, A. (2014). Flipped learning: Gateway to student engagement. International Society for Technology in Education.

Bruton, A. (2005). Task-based language teaching: For the state secondary FL classroom? Language Learning Journal, 31, 55-68.

Burns, A. (2016). Research and the teaching of speaking in the second language classroom. Handbook of 
research in second language teaching and learning, 3, 242-256.

Burrows, C. (2008). An evaluation of task-based learning (TBL) in the Japanese classroom. English Today, 24(4), 11-16. https://doi.org/10.1017/S0266078408000345

Carless, D. (2007). The suitability of task-based approaches for secondary schools: Perspectives from Hong Kong. System, 35, 595-608. https://doi.org/10.1016/j.system.2007.09.003

Chen Hsieh, J. S., Wu, W. C. V., \& Marek, M. W. (2017). Using the flipped classroom to enhance EFL learning. Computer Assisted Language Learning, 30(1-2), 1-21. https://doi.org/10.1080/09588221.2015.1111910

Clark, K. R. (2015). The Effects of the Flipped Model of Instruction on Student Engagement and Performance in the Secondary Mathematics Classroom. Journal of Educators Online, 12(1), 91-115.

Cockrum, T. (2013). Flipping your English class to reach all learners: Strategies and lesson plans. Routledge.

Costikyan, G. (1994). I have no words and I must design. Interactive Fantasy\# 2. British roleplaying journal.

Crawford, C. (1984). The art of computer game design.

DeFreitas, S. I. (2006). Using games and simulations for supporting learning. Learning, media and technology, 31(4), 343-358. https://doi.org/10.1080/17439880601021967

Dempsey, J. V., Haynes, L. L., Lucassen, B. A., \& Casey, M. S. (2002). Forty simple computer games and what they could mean to educators. Simulation \& Gaming, 33(2), 157-168 https://doi.org/10.1177/ 1046878102332003

Doughty, C., \& Varela, E. (1998). Communicative focus on form. Focus on form in classroom second language acquisition, 1, 114-138.

Ellis, R. (2003). Task-based language learning and teaching. Oxford University Press.

Flynn, A. B. (2015). Structure and evaluation of flipped chemistry courses: organic \& spectroscopy, large and small, first to third year, English and French. Chemistry Education Research and Practice, 16(2), 198-211.

Foley, J. (2005). English in Thailand. RELC, 36(2), 223-234

Foster, P., \& Ohta, A. S. (2005). Negotiation for meaning and peer assistance in second language classrooms. Applied linguistics, 26(3), 402-430. https://doi.org/10.1093/applin/ami014

Gaughan, J. E. (2014). The flipped classroom in world history. History Teacher, 47(2), 221-244.

Gibson, L. A., \& Sodeman, W. A. (2014). Millennials and technology: Addressing the communication gap in education and practice. Organization Development Journal, 32(4), 63-75.

Goh, C. C. M. (2007). Teaching speaking in the language classroom. Singapore: SEAMEO Regional Language Centre.

Horwitz, E. K., Horwitz, M. B., \& Cope, J. (1986). Foreign language classroom anxiety. The Modern Language Journal, 70(2), 125-132. https://doi.org/10.1111/j.1540-4781.1986.tb05256.x

Johnson, K. (1996). Language teaching and skill development. Oxford: Blackwell

Kang, S. J. (2005). Dynamic emergence of situational willingness to communicate in a second language. System, 33(2), 277-292. https://doi.org/10.1016/j.system.2004.10.004

Kanoksilapatham, B. (2007). Navigating pathways to success in ELT. Journal of English Studies, 3, 6-25.

Kapp, K. M. (2012). The gamification of learning and instruction: game-based methods and strategies for training and education. John Wiley \& Sons.

Kapp, K. M., Blair, L., \& Mesch, R. (2014). The gamification of learning and instruction fieldbook: Ideas into practice. John Wiley \& Sons.

Khamkhien, A. (2010). Teaching English Speaking and English Speaking Tests in the Thai Context: A Reflection from Thai Perspective. English Language Teaching, 3(1), 184-190.

Kotlik, R. H. (2014). The flipped model in an advanced placement United States history course. Promoting active learning through the flipped classroom model, 208-225.

Köroğlu, Z. Ç., \& Çakır, A. (2017). Use of Flipped Instruction in Language Classrooms; An Investigation About Student Teachers' Perceptions. European Journal of English Language Teaching.

Lee, W. R. (1979). Language teaching games and contests: Teacher's library. Oxford: Oxford University Press. 
Lee, S. J., \& Reeves, T. C. (2007). Edgar Dale: A significant contributor to the field of educational technology. Educational Technology, 47(6), 56.

Littlewood, W. (2007). Communicative and task-based language teaching in East Asian classrooms. Language Teaching, 40, 243-249. https://doi.org/10.1017/S0261444807004363

Loschky, L. (1994). Comprehensible input and second language acquisition: What is the relationship? Studies in Second Language Acquisition, 16(3), 303-323. https://doi.org/10.1017/S0272263100013103

Lyster, R. (2004). Differential effects of prompts and recasts in form-focused instruction. Studies in Second Language Acquisition, 26(3), 399-432. https://doi.org/10.1017/S0272263104263021

MacIntyre, P. D., Dörnyei, Z., Clément, R., \& Noels, K. A. (1998). Conceptualizing willingness to communicate in a L2: A situational model of L2 confidence and affiliation. The Modern Language Journal, 82(4), 545-562. https://doi.org/10.1111/j.1540-4781.1998.tb05543.x

Malone, T. W. (1980, August).What makes things fun to learn? A study of intrinsically motivating computer games. Xerox Palo Alto Research Center Technical Report No. CIS-7 (SSL-80-11), Palo Alto, California.

Matsuoka, R., \& Evans, D. R. (2005). Willingness to communicate in the second language. Journal of Nursing Studies, 4(1), 3-12.

McDonough, K., \& Chaikitmongkol, W. (2007). Teachers' and learners' reactions to a task-based EFL course in Thailand. Tesol Quarterly, 41(1), 107-132. https://doi.org/10.1002/j.1545-7249.2007.tb00042.x

McLaughlin, B., \& Heredia, R. (1996). Information-processing approaches to research on second language acquisition and use. Handbook of Second Language Acquisition, 213-228.

Meihami, B., Varmaghani, Z., \& Meihami, H. (2013). CALL in the Form of Simulation Games: Teaching English Vocabulary and Pronunciation through Sims. International Letters of Social and Humanistic Sciences, 8, 57-65.

Michigan Language Assessment. (2013). Speaking Rating Scale for Michigan English Language Assessment Battery (MELAB) 2013. Retrieved from https://michiganassessment.org/test-takers/tests/met/

Morris, C., \& Thomoasson, A. (2013). English. In J. Bretzmann (Ed.), Flipping 2.0: practical strategies for flipping your class (pp. 37-74). The Bretzmann Group, LLC.

Mustafa, Z. (2008, October 29-31). Teachers' levels of use in the adoption of task-based language teaching in Malaysian classrooms. Paper presented at the Third International Conference on Language Learning. USM, Penang.

Nation, I. S. P., \& Newton, J. (2009). Teaching ESL/EFL listening and speaking. Routledge.

Nunan, D. (1989). Designing Tasks for the Communicative Classroom, Cambridge University Press.

Nunan, D. (2004). Task-based language teaching. Ernst Klett Sprachen.

Noom-ura, S. (2008). Teaching listening speaking skills to Thai students with low English proficiency. Asian EFL Journal, 10(4), 173-192.

Noom-Ura, S. (2013). English-Teaching Problems in Thailand and Thai Teachers' Professional Development Needs. English Language Teaching, 6(11), 139-147.

Norris, J. M., \& Ortega, L. (2000). Effectiveness of L2 instruction: A research synthesis and quantitative metaanalysis. Language Learning, 50(3), 417-528. https://doi.org/10.1111/0023-8333.00136

Occupational English Test (2016). Speaking Assessment Criteria of Occupational English Test (OET) public version 2016, Retrieved from https://prod-wp-content.occupationalenglishtest.org/resources/uploads/2018/ 08/22102547/speaking-assessment-criteria-updated-2018.pdf

Ohta, A. S. (1995). Applying sociocultural theory to an analysis of learner discourse: Learner-learner collaborative interaction in the zone of proximal development. Issues in Applied Linguistics, 6(2), 93-121.

O’Sullivan, B \& Dunlea (2015). Tachnical Report: Aptis General Technical Manual Version 1.0, Retrieved from https://www.britishcouncil.org/sites/default/files/aptis_general_technical_manual_v-1.0.pdf

Pandey, I., \& Sinhaneti, K. (2013). A study of required English skills for healthcare personnel in Bangkok-Based International Hospitals. J Educ Vocational Res, 4(6), 184-92.

Parlett, D. S. (1999). The Oxford history of board games. Oxford University Press, USA. 
Pattapong, K. (2010). Willingness to communicate in a second language: A qualitative study of issues affecting Thai EFL learners from students' and teachers' point of view.

Prensky, M. (2007). Digital game-based learning (2nd ed.). St. Paul, MN: Paragon House

Purushotma, R., Thorne, S. L., \& Wheatley, J. (2009). 10 Key Principles for Designing Video Games for Foreign Language Learning.

Quyên, T. T. T., \& Lợi, N. V. (2018). Flipped model for improving students' English speaking performance. Tạp chí Khoa học Truoòng Đại học Cần Tho, 54, 90-97.

Rama, P. S., Black, R. W., van Es, E., \& Warschauer, M. (2012). Affordances for second language learning in World of Warcraft. ReCALL, 24(03), 322-338.

Reinhardt, J., \& Sykes, J. (2011). Framework for Game-enhanced Materials Development. Tucson, AZ: Center for Educational Resources in Culture. Language, and Literacy.

Rerkrujipimol, J., \& Assenov, I. (2011). Marketing strategies for promoting medical tourism in Thailand. Journal of Tourism, Hospitality \& Culinary Arts, 3(2), 95-105.

Richards, J. C. (2006). Teaching listening and speaking. Cambridge University Press.

Richards, J. C., \& Rodgers, T. S. (2014). Approaches and methods in language teaching. Cambridge University Press.

Saengboon, S. (2004). Second language acquisition (SLA) and English language teaching (ELT). PASAA. Bangkok, 35(1), 11-34.

Salen, K., \& Zimmerman, E. (2004). Rules of play: Game design fundamentals. MIT press.

Samuda, V., \& Bygate, M. (2008). Tasks in second language learning. Palgrave Macmillan.

Seery, M. K. (2014). Student Engagement with Flipped Chemistry Lectures.

Smith, J. D. (2013). Student attitudes toward flipping the general chemistry classroom. Chemistry Education Research and Practice, 14(4), 607-614.

Suits, B. (1990). The Grasshopper-: Games, Life and Utopia. Broadview Press.

Supakankunti, S., \& Herberholz, C. (2011). Trade in Health Services-Harnessing the Benefits and Avoiding the Pitfalls: The Case of Thailand. Bangkok, Thailand: Chulalangkorn University.

Skehan, P. (1998). A cognitive approach to language learning. Oxford University Press.

Spada, N., \& Lightbown, P. M. (2008). Form-focused instruction: Isolated or integrated? Tesol Quarterly, 42(2), 181-207. https://doi.org/10.1002/j.1545-7249.2008.tb00115.x

Spada, N., \& Lightbrown, P. (1993). Instruction and the development of questions in L2 classrooms. Studies in Second Language Acquisition, 15, 205-24. https://doi.org/10.1017/S0272263100011967

Swain, M., \& Lapkin, S. (1998). Interaction and second language learning: Two adolescent French immersion students working together. The Modern Language Journal, 82(3), 320-337. https://doi.org/10.1111/ j.1540-4781.1998.tb01209.x

Tasci, C. (2007). An Analysis of Medical Students' English language needs (Unpublished Master's Thesis. Bilkent University, Ankara).

Teng, M. F. (2018). Flip Your Classroom to Improve EFL Students' Speaking Skills. Innovations in Flipping the Language Classroom (pp. 113-122). Springer, Singapore.

Thailand Board of Investment. (2016, May). Thailand Investment Review, 26(5) 3-4. Retrieved from https://www.boi.go.th/upload/content/TIR_MAY_56933.pdf

Thailand Board of Investment. (2017, April). Thailand Investment Review, 27(4) 6. Retrieved from https://www.boi.go.th/upload/content/TIR_Apr17_40465.pdf

Thornbury, S. (2005). How to teach speaking. Longman.

Triantafyllou, E., \& Timcenko, O. (2015, February). Student perceptions on learning with online resources in a flipped mathematics classroom. In CERME 9-Ninth Congress of the European Society for Research in Mathematics Education (pp. 2573-2579).

Van den Branden, K. (2016). Task-based language teaching. The Routledge Handbook of English Language Teaching, 238-251. 
Waidarp, W. (2011). Demand of English Skills for Thai Nurses Working in an International Healthcare Organization: A Study in a Private Hospital in the Silom Area (Doctoral dissertation, THAMMASAT UNIVERSITY BANGKOK, THAILAND).

Whitton, N. (2010). Learning with digital games: A practical guide to engaging students in higher education. Routledge.

Willis, J. (1996). A framework for task-based learning. Pearson PTR.

Willis, D., \& Willis, J. (2007). Doing task-based teaching. Oxford University Press.

Wiriyachitra, A. (2001). A Thai university scenario in the coming decade. Thai TESOL Newsletter, 14, 4-7.

Wright, R. \& Cagnol, B, \& Symonds, M. S. (2012). English for Nursing Level 1, Pearson Longman, UK

Wright, R. \& Symonds, M. S. (2011). English for Nursing Level 2, Pearson Longman, UK

Xie, Q. M. (2011). Willingness to communicate in English among secondary school students in the rural Chinese English as a foreign language (EFL) classroom (Doctoral dissertation, Auckland University of Technology).

Yen, L., Chen, C. M., \& Huang, H. B. (2016, June). Effects of mobile game-based English vocabulary learning APP on learners 'perceptions and learning performance: A case study of Taiwanese EFL learners. International Conference on e-Learning (p. 255). Academic Conferences International Limited. https://doi.org/10.1017/S0958344018000228

Yip, F. W., \& Kwan, A. C. (2006). Online vocabulary games as a tool for teaching and learning English vocabulary. Educational Media International, 43(3), 233-249. https://doi.org/10.1080/09523980600641445

Young, D. J. (1990). An investigation of students' perspectives on anxiety and speaking. Foreign Language Annals, 23(6), 539-553. https://doi.org/10.1111/j.1944-9720.1990.tb00424.x

Zarrinabadi, N. (2014). Communicating in a second language: Investigating the effect of teacher on learners' willingness to communicate. System, 42, 288-295. https://doi.org/10.1016/j.system.2013.12.014

Zheng, D., Young, M. F., Wagner, M., \& Brewer, R. A. (2009). Negotiation for Action: English Language Learning in Game-Based Virtual Worlds. The Modern Language Journal, 93(4), 489-511. https://oi.org/10.1111/j.1540-4781.2009.00927.x

\section{Copyrights}

Copyright for this article is retained by the author(s), with first publication rights granted to the journal.

This is an open-access article distributed under the terms and conditions of the Creative Commons Attribution license (http://creativecommons.org/licenses/by/4.0/). 